\title{
Izolowany zawał prawej komory serca jako wynik ostrej zatorowości płucnej
}

\section{Isolated right ventricular infarction as a result of acute pulmonary embolism}

\author{
Marcin Koć ${ }^{1}$, Michał Ciurzyński ${ }^{1}$, Dorota Piotrowska-Kownacka ${ }^{2}$, Piotr Pruszczyk ${ }^{1}$ \\ ${ }^{1}$ Klinika Chorób Wewnętrznych i Kardiologii z Centrum Diagnostyki i Leczenia Żylnej Choroby Zakrzepowo-Zatorowej \\ Warszawskiego Uniwersytetu Medycznego \\ ${ }^{2}$ I Zakład Radiologii Klinicznej Warszawskiego Uniwersytetu Medycznego
}

\section{Streszczenie}

W przebiegu ostrej zatorowości płucnej (PE) często dochodzi do ostrego przeciążenia prawej komory, co wiąże się z pogorszeniem przebiegu choroby. Rozstrzeń jam prawej części serca pociąga za sobą pogorszenie czynności hemodynamicznej. W przypadku znacznego przeciążenia prawej komory w przebiegu ostrej PE może dojść również do niedokrwienia miokardium. Autorzy przedstawili przypadek młodej nieleczonej przewlekle kobiety, u której rozpoznano zawał prawej komory (RVMI) w przebiegu ostrej PE, a diagnozę potwierdzono za pomocą rezonansu magnetycznego serca (CMR).

Słowa kluczowe: zawał prawej komory, ostra zatorowość płucna, rezonans magnetyczny serca

(Folia Cardiologica 2015; 10, 6: 438-441)

\section{Wstęp}

W przebiegu ostrej zatorowości płucnej (PE, pulmonary embolism) często dochodzi do ostrego przeciążenia prawej komory, co wiąże się z pogorszeniem przebiegu choroby. Rozstrzeń jam prawej części serca pociąga za sobą pogorszenie czynności hemodynamicznej. W przypadku znacznego przeciążenia prawej komory w przebiegu ostrej PE może dojść również do niedokrwienia miokardium. Autorzy przedstawili przypadek młodej nieleczonej przewlekle kobiety, u której rozpoznano zawał prawej komory serca (RVMI, right ventricular myocardial infarction) w przebiegu ostrej PE, a diagnoze potwierdzono za pomocą rezonansu magnetycznego serca (CMR, cardiac magnetic resonance).

\section{Opis przypadku}

Kobieta w wieku 52 lat, paląca tytoń, została przyjęta do kliniki po omdleniu poprzedzonym kilkudniowym okresem narastającej duszności i kaszlu. Przy przyjęciu chora była w ciężkim stanie ogólnym, z nasiloną dusznością oraz niskim ciśnieniem tętniczym (95/50 mm Hg). W badaniu elektrokardiograficznym (EKG) stwierdzono typowe dla ostrej PE cechy ostrego uszkodzenia prawej komory oraz istotne uniesienie odcinka ST w odprowadzeniach prawokomorowych (ryc. 1). Stężenie troponiny T było podwyższone do $224 \mathrm{ng} / \mathrm{I}$ (norma < 14,00 ng/l), stężenie propeptydu natriuretycznego typu B (proBNP, pro B-type natriuretic peptide) natomiast wyniosło $2054 \mathrm{pg} / \mathrm{ml}$. W wykonanym badaniu tomografii komputerowej stwierdzono cechy masywnej radiologicznie ostrej PE (ryc. 2). Z tego powodu chora została skierowana na oddział intensywnej opieki kardiologicznej, gdzie wykonano echokardiografię serca uwidaczniającą cechy ostrej PE z przeciążeniem prawej komory (spłaszczanie przegrody międzykomorowej, obecny objaw MacConnella, podwyższona do $43 \mathrm{~mm}$ Hg wartość gradientu maksymalnego przez zastawkę trójdzielną [TRPG, transtricuspid pressure gradient] oraz stosunek wymiarów

Adres do korespondencji: lek. Marcin Koć, Klinika Chorób Wewnętrznych i Kardiologii, Warszawski Uniwersytet Medyczny, Szpital Kliniczny Dzieciątka Jezus, 02-005 Warszawa, ul. Lindleya 4, tel. 2250211 44, faks 2250221 42, e-mail: marcin.koc.pl@gmail.com 
A

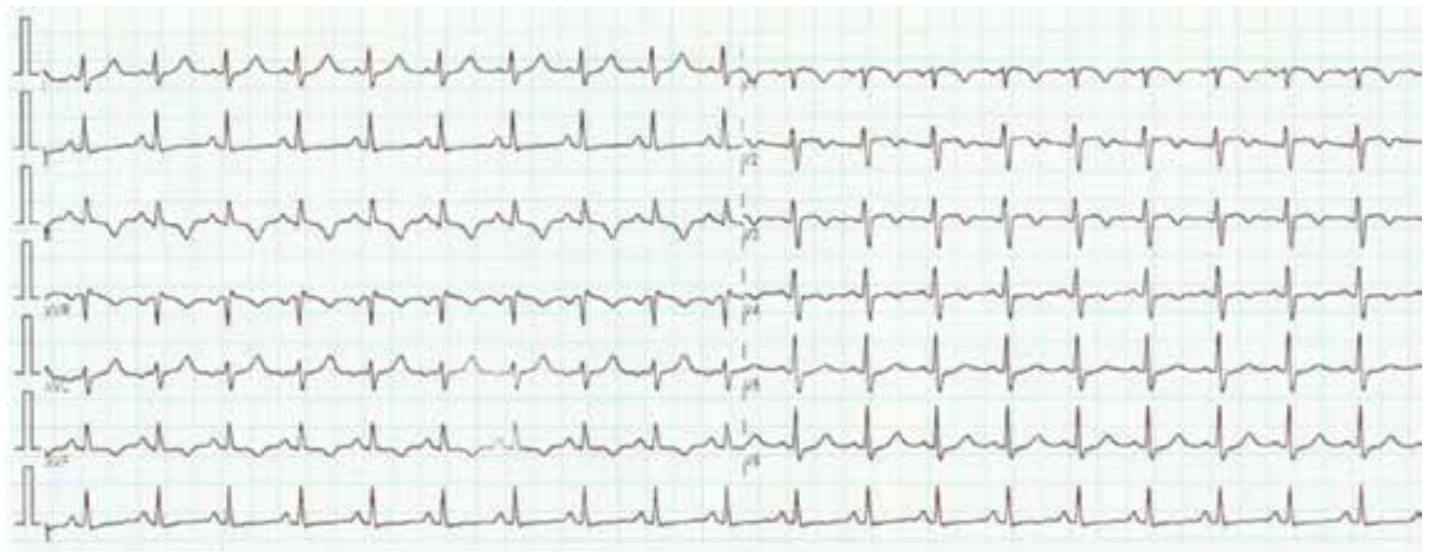

B

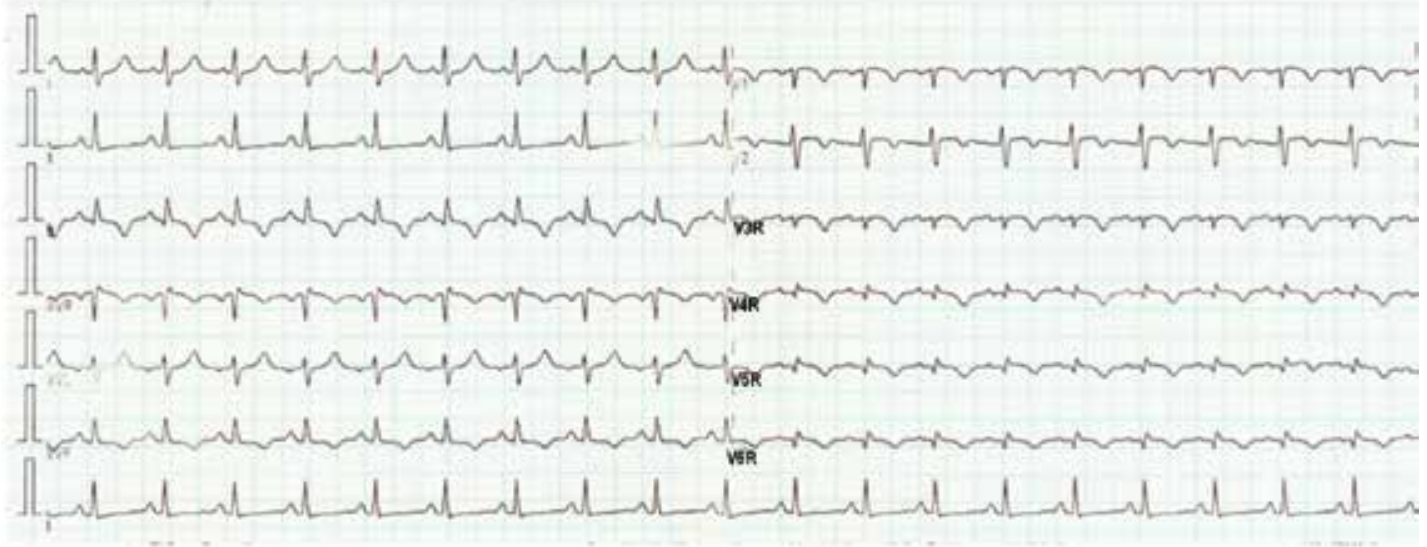

Rycina 1A, B. Dwunastoodprowadzeniowy zapis elektrokardiograficzny wykonany przy przyjęciu $(25 \mathrm{~mm} / \mathrm{s}, 10 \mathrm{~mm} / \mathrm{mV})$ : A. Zapis standardowy - tachykardia zatokowa 125/min, oś serca pośrednia, zespół SIQIIITIII, ujemne załamki T w odprowadzeniach aVF, V1-V4, graniczne uniesienie odcinka ST w odprowadzeniach aVR i V1; B. Odprowadzenia prawokomorowe - tachykardia zatokowa 125/min, istotne uniesienie odcinka ST w odprowadzeniach V3R-V5R

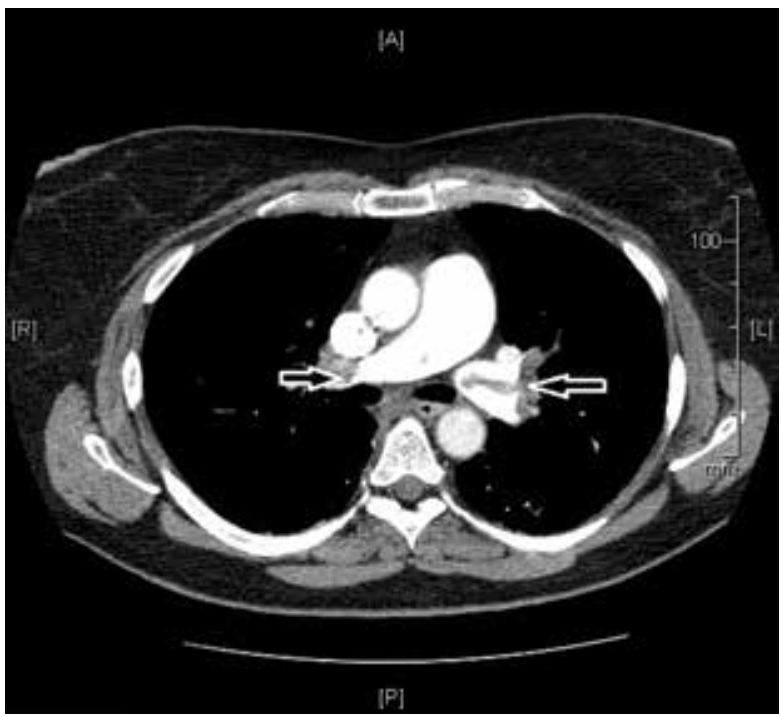

Rycina 2. Obraz tomografii komputerowej klatki piersiowej - protokół w kierunku zatorowości płucnej; obustronnie w tętnicach płucnych widoczne skrzepliny (zaznaczono strzałkami) prawej komory do lewej komory [RV/LV, right ventricle/left ventricle] $=1,1$ ).

Rozpoczęto leczenie heparyną niefrakcjonowaną (UFH, unfractionated heparin), jednak ze względu na rozwijający się wstrząs zastosowano trombolizę. Podano alteplazę w dawce $40 \mathrm{mg}$ (0,6 mg/kg mc.), zaś leczenie UFH kontynuowano pod kontrolą czasu częściowej tromboplastyny po aktywacji (APTT, activated partial thromboplastin time). Przewlekle zastosowano warfarynę $z$ docelową wartością międzynarodowego wskaźnika znormalizowanego (INR, international normalized ratio) w zakresie 2-3. Z powodu elektrokardiograficznych cech RVMI, wykonano CMR, stwierdzając opóźnione wzmocnienie sygnału odpowiadające świeżej martwicy miokardium (ryc. 3). W angiografii tętnic wieńcowych przeprowadzonej metodą tomografii komputerowej nie uwidoczniono istotnych zmian w naczyniach.

Na podstawie całości obrazu rozpoznano ostry zawał prawej komory serca w przebiegu ostrej PE wysokiego ryzyka według European Society of Cardiology (ESC). 


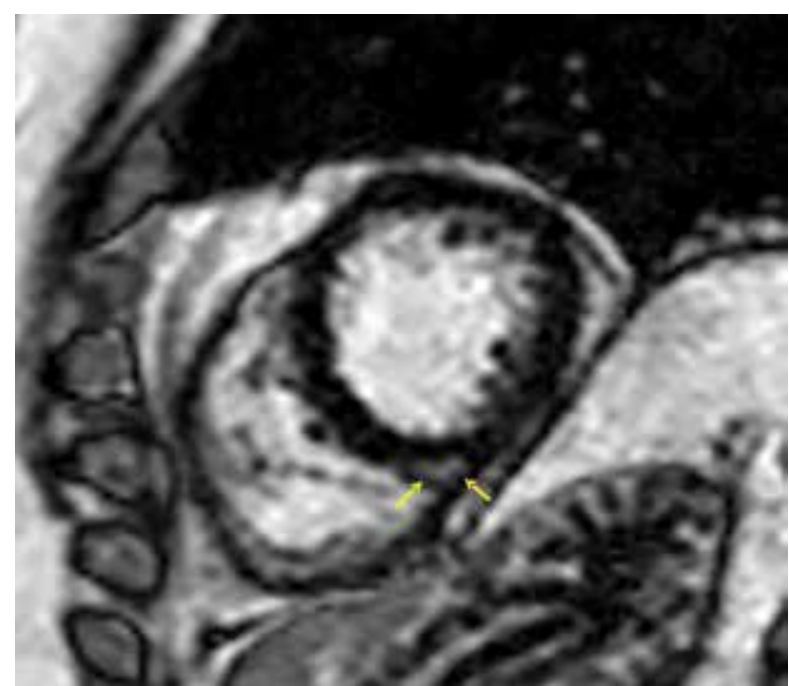

Rycina 3. Obraz T1-zależny rezonansu magnetycznego serca widoczny obszar opóźnionego wzmocnienia sygnału na granicy wolnej ściany prawej komory oraz przegrody międzykomorowej (zaznaczono strzałkami)

\section{Dyskusja}

Ostra zatorowość płucna jest często związana z dysfunkcją RV. U części chorych może przybierać postać jej zawału, co istotnie pogarsza przebieg choroby [1]. Zawał prawej komory serca rozpoznaje się u 1-85\% chorych z ostrymi zespołami wieńcowymi [2]. Gdy jego przyczyną są wyłącznie zmiany w tętnicach wieńcowych, występuje łącznie z zawałem w obrębie lewej komory serca (najczęściej ściany dolnej i tylnej). W eksperymentalnych badaniach na zwierzętach nie udało się wywołać izolowanej martwicy RV przez zamknięcie prawej tętnicy wieńcowej [3]. Dotychczasowe opisy izolowanego RVMI dotyczą wyłącznie chorych z ostrą PE lub przerostem RV. Potwierdzili to Coma-Canella i wsp. [4], którzy w materiale autopsyjnym 216 kolejnych chorych zmarłych na oddziale kardiologicznym stwierdzili izolowany RVMI w 8 przypadkach. U 6 z nich rozpoznano masywną zatorowość płucną, u 2 natomiast istotny przerost mięśnia RV. Do podobnych wniosków doszli Andersen i wsp. [2], analizując materiał sekcyjny 107 chorych. Tym razem w autopsji osób bez PE nie stwierdzono ani jednego przypadku izolowanego RVMI. Opisywano przypadki zawałów RV w przebiegu ostrej PE u chorych z prawidłowymi tętnicami wieńcowymi [5].

Przytoczone wyżej dane sugerują, że RVMI jest raczej skutkiem ostrej PE niż jej przyczyną [4]. Nagły wzrost ob- ciążenia następczego wynikający z upośledzonej drożności łożyska płucnego powoduje ostrą rozstrzeń RV i niedokrwienie miokardium. Hipoksemia towarzysząca ostrej PE dodatkowo ogranicza podaż tlenu do mięśnia RV. To z kolei prowadzi do dalszego upośledzenia sprawności RV i zmniejszenia rzutu serca skutkującego nasileniem niedokrwienia i w konsekwencji - martwicy mięśnia RV. Całkowicie odmienną przyczyną zawału u chorego z ostrą PE może być zatorowość paradoksalna przez drożny otwór owalny [6].

Istotnym problemem pozostaje rozpoznanie RVMI w przebiegu ostrej PE. Obie te choroby cechują zbliżone symptomatologia, standardowy zapis EKG i podwyższone stężenie biomarkerów uszkodzenia mięśnia sercowego. Również obraz echokardiograficzny uszkodzenia RV w przebiegu ostrej PE jest podobny do tego w RVMI [7]. W opisywanym przypadku uwage zwróciło istotne uniesienie odcinka ST w prawokomorowych odprowadzeniach EKG mogące świadczyć o ostrym RVMI [8]. Podejrzenie to zostało potwierdzone w CMR, w którym uwidoczniono obszar opóźnionego wzmocnienia sygnału odpowiadającego martwicy miokardium, co w połączeniu z prawidłowym obrazem naczyń wieńcowych pozwoliło na rozpoznanie izolowanego RVMI w przebiegu ostrej PE. Ze względu na wysoki koszt badania i jego ograniczoną dostępność trudno zalecać CMR jako technikę umożliwiającą różnicowanie RVMI z ostrą PE. Wydaje się jednak, że wykonanie EKG z odprowadzeń prawokomorowych może się przyczynić do częstszego rozpoznawania RVMI prowadzącego do identyfikacji chorych z gorszym spodziewanym przeżyciem wewnątrzszpitalnym. Zapis taki ma szczególną wartość u chorych z potwierdzonym przeciążeniem RV, a także u tych, u których w standardowym EKG stwierdza się nieprawidłowości mogące odpowiadać niedokrwieniu ścian dolnej i dolno-podstawnej.

\section{Podsumowanie}

1. Izolowany zawał prawej komory serca może współistnieć z ostrą PE, a jego wystąpienie istotnie pogarsza przebieg choroby. 2. Zasadne wydaje się wykonywanie EKG z odprowadzeń prawokomorowych w celu rozpoznania zawału RV. Szczególne znaczenie może to mieć u chorych z przeciążeniem RV oraz tych, u których w standardowym EKG występują zmiany niedokrwienne w obrębie ścian dolnej i dolno-podstawnej. 3. Badanie CMR jest cennym narzędziem ułatwiającym rozpoznanie zawału RV. 


\section{Abstract}

Acute pulmonary embolism (APE) often leads to acute right ventricular overload, which is associated with patient's condition deterioration. Dilation of the right chambers of the heart results in worsening in haemodynamic function. Severe overload of the right ventricle in the course of APE may also cause myocardial ischaemia. We present a case of young women who did not receive chronic treatment, in whom right ventricular myocardial infarction (RVMI) in the course of APE was diagnosed, and the diagnosis was confirmed with cardiac magnetic resonance (CMR) imaging.

Key words: right ventricular infarction, acute pulmonary embolism, cardiac magnetic resonance imaging

(Folia Cardiologica 2015; 10, 6: 438-441)

\section{Piśmiennictwo}

1. Konstantinides S.V., Torbicki A., Agnelli G. i wsp. 2014 ESC guidelines on the diagnosis and management of acute pulmonary embolism. Eur. Heart J. 2014; 35: 3033-3069, 3069a-3069k.

2. Andersen H.R., Falk E., Nielsen D. Right ventricular infarction: frequency, size and topography in coronary heart disease: a prospective study comprising 107 consecutive autopsies from a coronary care unit. J. Am. Coll. Cardiol. 1987; 10: 1223-1232.

3. Ratliff N.B., Peter R.H., Ramo B.W. i wsp. A model for the production of right ventricular infarction. Am. J. Pathol, 1970; 58: 471-480.

4. Coma-Canella I., Gamallo C., Martinez Onsurbe P. i wsp. Acute right ventricular infarction secondary to massive pulmonary embolism. Eur. Heart J. 1988; 9: 534-540.

5. Pruszczyk P., Szulc M., Horszczaruk G. i wsp. Right ventricular infarction in a patient with acute pulmonary embolism and normal coronary arteries. Arch. Intern. Med. 2003; 163: 1110-1111.
6. Wasek W.C., Samul W., Ryczek R.,Skrobowski A., Unique Case of ST-Segment-Elevation Myocardial Infarction Related to Paradoxical Embolization and Simultaneous Pulmonary Embolization: Clinical Considerations on Indications for Patent Foramen Ovale Closure in No-Guidelines Land. Circulation, 2015. 131(13): 1214-1223.

7. Casazza F., Bongarzoni A., Capozi A. i wsp. Regional right ventricular dysfunction in acute pulmonary embolism and right ventricular infarction. Eur. J. Echocardiogr. 2005; 6: 11-14.

8. Baranowski R., Kozłowski D., Kukla P. i wsp. Zalecenia dotyczące stosowania rozpoznań elektrokardiograficznych. Kardiol. Pol. 2010; 68 (supl. IV): 1-56. 